\title{
Penapisan Beberapa Isolat Pseudomonas fluorescens, Bacillus subtilis dan Trichoderma harzianum yang bersifat Antagonistik terhadap Ralstonia solanacearum pada Tanaman Kentang
}

\author{
Hersanti ${ }^{1}$, Rian Triyanti Rupendi ${ }^{1}$, Andang Purnama ${ }^{1}$, \\ Hanudin $^{2}$, Budi Marwoto ${ }^{2}$ dan Oni Setiani Gunawan ${ }^{3}$ \\ ${ }^{1}$ Jurusan Hama dan Penyakit Tumbuhan Fakultas Pertanian Unpad \\ Jalan Raya Jatinangor Km. 21 Bandung 40600 \\ 2Balai Penelitian Tanaman Hias, Jalan Raya Cipanas, Segunung, Cianjur \\ ${ }^{3}$ Balai Penelitian Tanaman sayuran \\ Jalan Tangkuban Parahu 517 Lembang, Bandung 40391 \\ Korespondensi: hersanti09@gmail.com
}

\section{ABSTRACT \\ Screening of some Isolate Pseudomonas fluorescens, Bacillus subtilis and Trichoderma harzianum to have the character antagonistic on Ralstonia solanacearum on potato}

Bacterial wilt disease caused by $R$. solanacearum is an important soilborne disease on potato. One of the alternative control methods which is environmental-friendly is the use of its antagonist P. fluorescens, B. subtilis, and T. harzianum. The objective of this experiment was to achieve the best isolate antagonist microbial to reduce the attack of bacterial wilt disease on potato. Two experiments were set up using Completely Block Design. The in vitro experiment was carried out to verify the inhibitation ability of three isolates $P$. Fluorescens, two isolates $B$. subtilis, one isolat B. cereus and three isolates T. Harzianum on the growth of $R$. solanacearum in King's B medium, while in vivo experiment was performed to find out the capacity of those isolates to supress bacterial wilt disease attack on potatoes. The result showed that isolates of T. harzianum 1, T. harzianum 2 and T. harzianum 3 could depress bacterial wilt disease on potato up to $77.21 \%, 77.21 \%$ and $63.57 \%$, respectively.

Key words: Antagonistic microbes, Bacterial wilt disease, Potato, Ralstonia solanacearum.

\begin{abstract}
ABSTRAK
Penyakit layu bakteri yang disebabkan oleh $R$. solanacearum merupakan salah satu penyakit penting yang menyerang tanaman kentang. Salah satu alternatif pengendalian yang ramah lingkungan adalah menggunakan mikroba antagonis seperti Pseudomonas fluorescens, Bacillus subtilis, dan Trichoderma harzianum. Tujuan penelitian adalah untuk mendapatkan isolat mikroba antagonis terbaik yang paling menekan penyakit layu bakteri pada tanaman kentang. Dua percobaan pada penelitian ini menggunakan Rancangan Acak Lengkap. Percobaan in vitro menguji daya hambat tiga isolat P. Fluorescens, dua isolat B. subtilis, satu isolat B. cereus dan 3 isolat $T$. harzianum terhadap perkembangan koloni $R$. solanacearum pada media King's B. Percobaan in vivo menguji kemampuan seluruh isolat terhadap penekanan serangan penyakit layu pada tanaman kentang. Hasil percobaan menunjukkan bahwa isolat T. harzianum 1, T. harzianum 2 dan T. harzianum 3 mampu menekan penyakit layu bakteri pada tanaman kentang dengan persentase penghambatan berturut-turut $77,21 \%, 77,21 \%$, dan 63,57 \%.
\end{abstract}

Kata kunci: Mikroba antagonis, Penyakit layu bakteri, Kentang, Ralstonia solanacearum 


\section{PENDAHULUAN}

Kentang merupakan salah satu produk tanaman yang berpotensi untuk diversifikasi pangan. Tanaman kentang juga menjadi salah satu komoditas pangan di Indonesia yang sudah diekspor. Produksi kentang Indonesia mengalami pertumbuhan rata-rata $5 \%$ per tahun dan mencapai lebih dari 1 juta ton pada tahun 2006 dengan luas areal tanam 60.000 ha tetapi hanya dapat memenuhi $10 \%$ konsumsi nasional, yaitu 8,9 juta ton per tahun. Di samping produksi yang belum cukup, volume dan nilai ekspor kentang sejak 1998 (31.204 ton atau senilai US\$ 5,88 juta) terus mengalami penurunan (Bisnis Indonesia Online, 2008).

Kendala dalam peningkatan produksi kentang di Indonesia adalah antara lain serangan hama dan penyakit tanaman. Salah satu patogen penyebab penyakit yang cukup merugikan dalam pertanaman kentang adalah bakteri Ralstonia solanacearum yang menimbulkan gejala layu pada tanaman dan gejala lanjut berupa umbi menjadi busuk. Pada jenis-jenis kentang yang rentan, penyakit layu dapat menyebabkan kerugian sampai $40 \%$ (Semangun, 2002).

Salah satu pengendalian penyakit layu bakteri yang aman bagi lingkungan adalah penggunaan mikroba antagonis. Beberapa mikroba antagonis yang telah banyak diteliti adalah Bacillus subtilis, Pseudomans fluorescens, dan Trichoderma harzianum. Ketiga isolat mikroba tersebut telah diuji sebelumnya untuk mengendalikan penyakit $R$. solanacearum dan penyakit lain pada tanaman tomat, tembakau, kacang, nilam, jahe, dan krisan. Basillus subtilis, P. fluorescens dan T. harzianum mampu menurunkan intensitas penyakit yang disebabkan $R$. solanacearum pada jahe sebesar $4 \%$ (Bustamam, 2006). T. harzianum juga mampu memberikan hasil terbaik dalam mengendalikan Sclerotium rolfsii pada tanaman kacang dengan kapasitas penekanan sebesar 12,07 \% (Kuswinanti, 2006). $P$. fluorescens dan $T$. harzianum sangat potensial untuk dikembangkan sebagai agen pengendali patogen tanaman hias, khususnya layu fusarium pada krisan (Wuryaningsih, 2009). P. fluorescens secara nyata dan konsisten juga menekan serangan Fusarium oxysporum f.sp tracheiphilum pada krisan sebanyak 72,51 \% (Hanudin et al., 2004).

Balai Penelitian Tanaman Hias (Balithi) mengkoleksi beberapa strain mikroba antagonis yaitu B. subtilis yang berasal di antaranya dari rizosfer anyelir, krisan di Segunung dan amarilis di
Cibadak, beberapa strain $P$. fluorescens di antaranya berasal dari daun Anthurium serta rizosfer cabai, krisan, anyelir dan tomat, Strain Trichoderma harzianum yang juga dikoleksi ITB, UGM dan Segunung. Pada penelitian ini seluruh isolat tersebut akan diuji kemampuannya dalam menekan penyakit layu bakteri yang disebabkan Ralstonia solanacearum pada tanaman kentang.

\section{METODE PENELITIAN}

Percobaan in vitro dilaksanakan di laboratorium Bakteriologi dan Mikologi, Balai Penelitian Tanaman Hias Segunung, Cianjur sedangkan percobaan in vivo dilaksanakan di rumah kaca Penyakit Balai Penelitian Tanaman Sayuran, Lembang. Seluruh percobaan dilaksanakan pada bulan Maret 2009 sampai dengan Juli 2009.

\section{Mikroba}

Tiga isolat Pseudomonas yaitu $P$. fluorescens 2, $P$. fluorescens 4 dan $P$. fluorescens 9 disediakan oleh Balithi yang masing-masing diisolasi dari rizosfer krisan, anyelir dan cabe yang tumbuh di Segunung. Isolat B. subtilis 14 diperoleh dari Balithi yang diisolasi dari rizosfer Amarilis yang tumbuh di Cibadak, Sukabumi. Bacillus Subtilis 12 dan $B$. cereus diperoleh dari Institut Pertanian Bogor. Tiga isolat Trichoderma yaitu $T$. harzianum 1 diperoleh dari Universitas Gajah Mada, T. harzianum 2 diperoleh dari Balithi dan T. harzianum 3 diperoleh dari ITB.

\section{Percobaan in vitro}

Metode penelitian adalah metode eksperimen yang dirancang dalam Rancangan Acak Lengkap dengan tiga ulangan. Percobaan rumah kaca ini menguji daya antagonis sembilan isolat mikroba dengan kontrol negatif berupa tanpa pemberian mikroba maupun bakterisida.

Media uji yang digunakan adalah $10 \mathrm{~mL}$ agar King's B yang ditempatkan pada cawan Petri berdiameter $9 \mathrm{~cm}$. Pada bagian tengah dan sisi media agar ditempatkan cakram kertas saring steril berdiameter $0,5 \mathrm{~cm}$ yang telah dicelupkan ke dalam masing-masing suspensi bakteri antagonis. Untuk menumbunkan jamur T. harzianum, Susupensi spora T. harzianum diambil dengan loop dan digoreskan di atas permukaan media agar sepanjang $3 \mathrm{~cm}$. Kultur tersebut kemudian disimpan di dalam inkubator selama 24 jam pada suhu $27{ }^{\circ} \mathrm{C}$. Kerapatan sel suspensi P. Fluorescens, B. Subtilis dan $B$. cereus adalah $10^{7} \mathrm{cfu} \mathrm{mL}^{-1}$ sedangkan 
kepadatan spora suspensi T. harzianum adalah $10^{6}$ spora $\mathrm{mL}^{-1}$.

Pengujian antagonisme antara mikroba antagonis dan $R$. solanacearum dilakukan dengan cara menyemprotkan suspensi $R$. solanacearum kerapatan $10^{9} \mathrm{cfu} \mathrm{mL} \mathrm{m}^{-1}$ dengan menggunakan sprayer ke atas permukaan petridish yang berisi biakan mikroba antagonis. Setelah 24 jam inkubasi pada suhu $27{ }^{\circ} \mathrm{C}$, diamati lebar zona hambatan di sekeliling mikroba antagonis. Areal hambatan terpanjang dari masing-masing isolat merupakan variabel penentu isolat terbaik untuk menseleksi efektivitas antagonis terhadap $R$. solanacearum. Seluruh isolat tersebut kemudian diuji lebih lanjut secara in vivo di rumah kaca.

\section{Percobaan in vivo}

Percobaan ini dirancang dalam Rancangan Acak Kelompok dengan tiga ulangan. Perlakuan yang diuji adalah sembilan isolat mikroba dengan kontrol positif berupa bakterisida dengan bahan aktif streptomisin sulfat $15 \%$ dan oksitetrasiklin $5 \%$. Kontrol negatif tanpa perlakuan mikroba maupun bakterisida.

Pada percobaan in vivo, bibit kentang varietas Granola ditanam dalam polibeg diameter 40 $\mathrm{cm}$ yang berisi $5 \mathrm{~kg}$ campuran tanah dan pupuk kandang (1:1; v:v) yang telah dipasteurisasi dan telah diinokulasi $R$. solanacearum dengan mengadopsi metode Hanudin (1995). Bakteri R. solanacearum yang ditumbuhkan pada media Tetrazolium Cloride (TZC) dipanen dengan menambahkan $10 \mathrm{~mL}$ aquades steril, dan dikeruk dengan menggunakan tabung kaca L. Suspensi bakteri diperbanyak pada media Nutrient Broth sebanyak $500 \mathrm{~mL}$ yang ditempatkan di atas pengocok selama 24 Jam. Setiap polibeg diinokulasi dengan suspensi $R$. solanacearum sebanyak $25 \mathrm{~mL}$ dengan penambahan $100 \mathrm{ml}$ aquades.

Aplikasi $P$. fluorescens, B. subtilis, B. cereus dan $T$. harzianum dilakukan dengan merendam bibit kentang selama 10 menit kemudian diikuti dengan menyiramkan suspensi mikroba sebanyak 75 $\mathrm{mL}$. Aplikasi kedua dilakukan 14 hari setelah tanam dengan cara menyiramkan $75 \mathrm{~mL}$ suspensi mikroba. Konsentrasi suspensi P. Fluorescens, B. Subtilis dan $B$. cereus yang digunakan adalah $10^{9} \mathrm{cfu} \mathrm{mL}^{-1}$ dan T. harzianum adalah $10^{7}$ spora $\mathrm{mL}^{-1}$. Populasi tanaman pada percobaan ini adalah 10 tanaman per perlakuan sehingga seluruhnya terdapat 330 tanaman.

Respons yang diamati pada percobaan in vivo meliputi waktu inkubasi dan persentase tanaman terserang bakteri $R$. solanacearum. Waktu inkubasi diamati setiap hari sampai 60 hari setelah tanam (HST). Persentase tanaman terserang yang diukur pada hari ke 36, 42 dan 46 dihitung dengan rumus:

$\%$ tanaman terinfeksi $=$

$$
\frac{\text { Jumlah tanaman yang terinfeksi }}{\text { Jumlah tanaman sampel }} \times 100 \%
$$

\section{Analisis Statistik}

Data dianalisis dengan analisis ragam menggunakan Uji F pada taraf $5 \%$ dan jika terdapat perbedaan yang nyata pengujian dilanjutkan dengan Uji Jarak Berganda Duncan pada taraf $5 \%$.

\section{HASIL DAN PEMBAHASAN}

Pada pengujian secara in vitro didapatkan hasil bahwa isolat-isolat bakteri P. fluorescens, B. subtilis, jamur T. harzianum mampu menekan perkembangan $R$. solanacearum pada media King's B. Panjang areal hambatan masing-masing mikroba antagonis dapat dilihat pada Tabel 1 .

Tabel 1. Panjang areal hambatan mikroba antagonis Ralstonia solanacearum pada media King's B

\begin{tabular}{lc}
\hline \multicolumn{1}{c}{ Mikroba antagonis } & $\begin{array}{c}\text { Panjang Areal } \\
\text { Hambatan }(\mathrm{cm})\end{array}$ \\
\hline P. fluorescens 2 (Pf2) & $4,17 \mathrm{~d}$ \\
P. fluorescens 4 (Pf4) & $3,00 \mathrm{c}$ \\
P. fluorescens 9 (Pf9) & $3,87 \mathrm{~d}$ \\
B. subtilis 14 (Ba14) & $2,13 \mathrm{~b}$ \\
B. subtilis 12 (Bs12) & $3,83 \mathrm{~d}$ \\
B. cereus 13 (Bc13) & $2,20 \mathrm{~b}$ \\
T. harzianum UGM (Th1) & $3,33 \mathrm{c}$ \\
T. harzianum Segunung (Th2) & $3,27 \mathrm{c}$ \\
T. harzianum ITB (Th3) & $2,40 \mathrm{~b}$ \\
Kontrol (K) & $0,00 \mathrm{a}$ \\
\hline
\end{tabular}

Keterangan : Nilai rata-rata yang diikuti huruf yang sama pada kolom yang sama menunjukkan tidak berbeda menurut Uji Jarak Berganda Duncan pada taraf $5 \%$.

Isolat Pf 2 (asal rizosfer krisan), Pf 9 (asal rizosfer cabai) dan Bs 12 (isolat dari IPB) memperlihatkan areal hambatan tertinggi di antara isolat yang diuji. Kemampuan isolat mikroba dalam menekan $R$. solanacearum disebabkan oleh kompetisi ruang seperti yang diperlihatkan pada mikroba $T$. harzianum dan antibiosis pada P. fluorescens dan B. subtilis. 
Tabel 2. Masa inkubasi dan persentase tanaman kentang yang layu akibat serangan bakteri Ralstonia solanacearum

\begin{tabular}{lccccc}
\hline \multirow{2}{*}{ Mikroba antagonis } & Masa inkubasi & \multicolumn{3}{c}{ Tanaman Layu (\%) } & Hambatan \\
\cline { 3 - 5 } & $(\mathrm{HST})$ & 36 HST & $42 \mathrm{HST}$ & $49 \mathrm{HST}$ & $(\%)$ \\
\hline P. fluorescens 2 (Pf2) & 38 & $0 \mathrm{a}$ & $3,3 \mathrm{a}$ & $40 \mathrm{abc}$ & 45,42 \\
P. fluorescens 4 (Pf4) & 38 & $0 \mathrm{a}$ & $10 \mathrm{a}$ & $50 \mathrm{abc}$ & 31,78 \\
P. fluorescens 9 (Pf9) & 41 & $0 \mathrm{a}$ & $10 \mathrm{a}$ & $33,3 \mathrm{abc}$ & 54,57 \\
B. subtilis 4 (Ba14) & 41 & $0 \mathrm{a}$ & $3,3 \mathrm{a}$ & $30 \mathrm{abc}$ & 59,07 \\
B. subtiilis 12 (Bs12) & 38 & $0 \mathrm{a}$ & $3,3 \mathrm{a}$ & $73,3 \mathrm{c}$ & 0,00 \\
B. cereus 13 (Bc13) & 38 & $0 \mathrm{a}$ & $3,3 \mathrm{a}$ & $30 \mathrm{abc}$ & 59,07 \\
T. harzianum UGM (Th1) & 38 & $0 \mathrm{a}$ & $3,3 \mathrm{a}$ & $16,7 \mathrm{ab}$ & 77,21 \\
T. harzianum Segunung (Th2) & 38 & $0 \mathrm{a}$ & $3,3 \mathrm{a}$ & $16,7 \mathrm{ab}$ & 77,21 \\
T. harzianum ITB (Th3) & 36 & $3,3 \mathrm{a}$ & $6,7 \mathrm{a}$ & $26,7 \mathrm{ab}$ & 63,57 \\
Kontrol & 38 & $0 \mathrm{a}$ & $6,7 \mathrm{a}$ & $73,3 \mathrm{c}$ & 0,00 \\
Bakterisida & 49 & $0 \mathrm{a}$ & $0,0 \mathrm{a}$ & $3,3 \mathrm{a}$ & 95,49 \\
\hline
\end{tabular}

Keterangan: Nilai rata-rata yang diikuti huruf yang sama pada kolom yang sama menunjukkan tidak berbeda menurut Uji Jarak Berganda Duncan pada taraf $5 \%$

Kemampuan $P$. fluorescens dalam menghambat $R$. solanacearum didukung oleh hasil penelitian Chet (1987) bahwa $P$. fluorescens menghasilkan antibiotik pyuloteorin, oomycin, phenazine-1-carbo-xylic acid atau 2,4diphloroglucinol yang efektif menghambat perkembangan bakteri ataupun jamur patogen.

Berdasarkan data pada Tabel 1, diduga $T$. harzianum hanya mampu menghasilkan antibiotik yang sedikit lebih rendah dibandingkan dengan bakteri $P$. fluorescens dan $B$. subtilis untuk mengendalikan patogen bakteri $R$. Solanacearum. Hal ini diduga karena daya hambat $T$. harzianum lebih efektif untuk patogen dari golongan jamur. Kemampuan sifat antibiosis jamur lebih rendah dibandingkan dengan bakteri. Namun penelitian lain menyebutkan bahwa bakteri $T$. harzianum dapat menginduksi sifat resisten tanaman kapas terhadap serangan bakteri (Howell, et al. 2000 dikutip Bustaman, 2006). Dengan demikian T. harzianum dapat digunakan untuk menambah keefektifan $P$. fluorescens dan B. subtilis dalam menekan penyakit layu bakteri.

Periode inkubasi merupakan periode waktu yang dibutuhkan oleh patogen sejak penetrasi hingga timbul infeksi yang diekspresikan melalui gejala yang dapat dilihat pada tanaman atau bagian tanaman. Data pada Tabel 2 menunjukkan bahwa gejala layu tanaman kentang yang paling cepat terjadi pada perlakuan Th3 yaitu 36 hari setelah tanam (HST). Masa inkubasi terlama terdapat pada aplikasi bakterisida yaitu 49 HST sedangkan masa inkubasi terlama pada tanaman kentang yang diberi mikroba antagonis terdapat pada perlakuan Pf9 dan Ba14 yaitu 41 HST. Masa inkubasi penyakit pada perlakuan Pf2, Pf4, Bs12, Bc13, Th1 dan Th2 adalah 38 hari.

Berdasarkan data Tabel 2, diketahui bahwa gejala serangan $R$. solanacearum muncul antara 36-49 HST. Menurut Nur Aeny (2001), masa inkubasi bakteri patogen ini tergantung dari daya virulensinya terhadap masing-masing tanaman inang dengan kisaran masa inkubasi antara 14-39 hari. Masa inkubasi ini dipengaruhi oleh beberapa faktor diantaranya tanaman inang, lingkungan, dan patogen. Konsentrasi dan virulensi bakteri patogen, serta ketahanan dari tanaman berperan dalam menentukan berapa lama waktu yang dibutuhkan bakteri untuk menimbulkan gejala awal (Samanhudi, 2001).

Pada umur tanaman kentang umur 36 HST dan 42 HST persentase tanaman layu pada semua perlakuan tidak berbeda nyata (Tabel 2). Persentase tanaman layu bakteri pada kedua pengamatan ini berkisar antara $0 \%$ samapai $10 \%$. Peningkatan persentase pentakit layu bakteri yang sangat tinggi terjadi pada pengamatan 49 HST. Persentase tanaman layu tertinggi terjadi pada perlakuan Bs12 yaitu $73,3 \%$ yang tidak berbeda nyata dengan kontrol negatif. Persentase tanaman layu yang terendah terdapat pada tanaman yang diberi bakterisida. Di antara tanaman yang diberi mikroba 
antagonis, persentase tanaman layu terendah diperlihatkan oleh perlakuan Th1, Th2 dan Th3 meskipun jika mengabaikan statistik maka persentase tanaman layu pada perlakuan Th3 lebih besar daripada Th1 dan Th2.

Persentase hambatan terhadap penyakit layu bakteri di atas $50 \%$ terdapat pada tanaman kenting yang diberi perlakuan Pf 9, Bs. 4, Bs12, Bc.13, Th1, Th. 2 dan Th. 3 dan bakterisida. Persentase penghambatan layu bakteri tertinggi terdapat pada perlakuan $T$. harzianum. Kemampuan $T$. harzianum dalam menekan penyakit layu bakteri didukung penelitian Maketon (2008) yang membuktikan bahwa aplikasi $T$. harzianum dapat menekan serangan $R$. Solanacearum penyebab penyakit layu bakteri pada tanaman tembakau sebesar $80 \%$. Di akhir percobaan, persentase penghambatan total ketiga isolat $\mathrm{T}$. harzianum adalah 77,21, 77,21 dan 63,57 masing-masing untuk isolat Th1, Th2 dan Th3. Persentase penghambatan penyakit layu bakteri pada tanaman kentang oleh $T$. harzianum lebih tinggi daripada oleh mikroba lainnya meskipun pada pengujian in vivo zona hambatan Th1 dan Th2 lebih kecil daripada ketiga isolat $P$. Fluorescens dan B. subtilis 12 .

\section{SIMPULAN}

Hasil penapisan beberapa isolat Pseudomonas fluorescens, Bacillus subtilis, Bacillus cereus dan Trichoderma harzianum yang bersifat antagonistik terhadap Ralstonia solanacearum pada tanaman kentang memberikan simpulan bahwa:

1. Secara in vitro isolat $P$. fluorescens $2, B$. subtilis 12, dan $T$. harzianum 1 merupakan isolat yang terbaik dalam menekan $R$. solanacearum.

2. Isolat $T$. harzianum 1, T. harzianum 2, dan T. harzianum 3 mampu menekan penyakit layu bakteri pada tanaman kentang dengan persentase penghambatan berturut-turut $77,21 \%$, $77,21 \%$ dan $63,57 \%$.

\section{DAFTAR PUSTAKA}

Bisnis Indonesia Online. 2008. Harga Benih Kentang Semakin Mahal. http://www.w3.org/TR/html (Diakses 23 April 2009)

Baker, KF and RJ Cook. 1983. The Nature and Practise of Biological Control of Plant pathogens. American phytopathology society. St. Paul. Minnessota. 538 pp.
Chet, I. 1987. Innovative Approaches to Plant Disease Control. Edisi II. The Hebrew University of Jerusalem, Rehovot.

Bustaman. 2006. Seleksi mikroba rhizosfer antagonis terhadap bakteri pada tanaman jahe di lahan tertindas. Jurnal Ilmu-ilmu Pertanian Indonesia 8: 12-18.

Choi GJ, JC Kim, EJPark, YH Choi, KS Jang, HK Lim, KY Cho and SW Lee. 2006. Biological Control activity of two isolates Pseudomonas fluorescens against rice sheath blight. Plant Pathol. J. 22: 289-294.

Djatmiko, HA, T Arwiyanto, T Hadisutrisno dan BH Sunarminto. 2007. Potensi tiga genus bakteri dari tiga rizosfer tanaman sebagai agensia pengendali hayati penyakit lincat. Jurnal Ilmu-Ilmu Pertanian Indonesia. 9: 40-47.

Gunawan. OS. 1987. Taksiran kehilangan hasil produksi kentang yang disebabkan oleh Pseudomonas solanacearum Smith. Bull. Penel. Hort. 25: 100-103.

Hanudin, B Marwoto, A Saepuloh, Mulya dan M Machmud. 2004. Formula cair Pseudomonas fluorescens untuk pengendalian penyakit layu fusarium pada Anyelir (Abstrak). Jurnal Penelitian Tanaman Hias. http://balithi.litbang.deptan.go.id. (Diakses 4 Mei 2009)

Hanudin, 2009. Mikroba antagonis sebagai agen hayati pengendali penyakit tanaman. Jurnal Penelitian Tanaman Hias.

http://balithi.litbang.deptan. Go.id. (Diakses 5 April 2009).

Kuswinanti, T. 2006. Efetivitas Trichoderma harzianum dan Gliocladium virens dalam menekan pertumbuhan Sclerotium rolfsii penyebab penyakit busuk pangkal batang pada tanaman kacang tanah (Abstrak). Buletin Penelitian vol 9 no.1.

http:/ijonline.net/index.php/BullPen/article /view/247 (Diakses 5 April 2009).

Maketon, M, A Jirasak and S Chatchai. 2008. Green house evaluation of Bacillus subtilis Ap-01 and Trichoderma harzianum AP-001 in controlling tobacco diseases. Brazilian J. Microbiol. 39:296-300.

Nur Aeny, T. 2001. Patogenesitas bakteri layu pisang (Ralstonia sp.) pada beberapa tanaman. Jurnal Hama dan Penyakit Tumbuhan Tropika 1: 60-62. 
Nuryani. W, Hanudin, E. Silvia, Suhardi dan Muhidin. 2004. Pengendalian hayati penyakit layu Fusarium oxysporum f.sp. dianthi pada anyelir. Prosiding Seminar Nasional Florikultura, Puslitbang Hortikultura. Hal. 143-147.

Purwantisari S, A Priyatmojo dan B Raharjo 2008. Produksi biofungisida berbahanbaku mikroba antagonis indigenous untuk penyakit lodoh tanaman kentang di sentra-sentra penanaman kentang di Jawa. http://balitbangjateng.go.id/kegiatan/rud/20 08/8-biofungisida.pdf. (Diakses 16 Juni 2009).

Samanhudi. 2009. Skrining ketahanan klon kentang terhadap penyakit layu bakteri. Fakultas Pertanian Universitas Sebelas Maret. http://pertanian.uns.ac.id. (Diakses 16 Juni 2009).

Semangun, H. 2002. Penyakit-penyakit Tanaman Hortikultura di Indonesia. Gadjah Mada Press. Yogyakarta. 850 hal.

Widarto, HT, 2008. Mendongkrak kinerja mikroorganisme antagonis terhadap patogen tular tanah. http://ditjenbun.deptan.go.id/ perlinbun/linbu. (Diakses 4 Mei 2009).

Wuryaningsih, S. 2009. Pemanfaatan Pseudomonas fluorescens, Gliocladium dan Trichoderma untuk mengendalikan penyakit layu fusarium pada tanaman krisan. Prosiding seminar Nasional Florikultura, Puslitbang Hortikultura. Hal. 271-278. 